\title{
Molecular Characterization of Seedlings Derived from Two Polyemberyonic Egyptian Mango Cultivars Using SSR Markers
}

\author{
Aboalmagd M. Soliman; Manal Eid; S. M. Greish; Mohamed A. Hussein* \\ Suez Canal University, Faculty of Agriculture, Department of Agriculture Botany, Ismailia, Egypt, 41522
}

Received: $18 / 06 / 2020$

\begin{abstract}
The molecular characterization and genetic variability between two of commercial and polyemberyonic Egyptian mango cultivars, namely: Zebda and Ewais, with thirty seedlings of their offspring were analyzed using 8 Simple Sequences Repeat (SSR) markers. LMMA_15 marker was discarded in data analysis because of producing only one band (monomorphic locus). Other seven markers produced total of 22 alleles with a high level of Polymorphism ( $\sim 100$ percent). The effective number of alleles ranged from 1.7 , to 3.4 with average value of 1.47 . Heterozygosity per locus varied from 0.00 to 0.75 with an average of 0.36 . Polymorphic Information content (PIC) value scored from 0.41 to 0.70 with average of 0.57 . The discrimination power $(\mathrm{Dp})$ ranged between 0.11 and 0.72 with an average of 0.50 per locus. Generally, the genetic similarity values varied between 0.12 and $100 \%$ over 32 genotypes. A cluster analysis was used to determine genetic similarities. The dendrogram can be grouped into two major clusters (I and II). Cluster I consists of Ewais seedlings exhibiting $94-100 \%$ genetic similarity among them. Cluster II consists of all seedlings of Zebda cultivar exhibiting 52-100\% genetic similarity and divided to two sub clusters. Seedling (Z_C_S2) was the most divergent in first sub cluster and second sub cluster exhibited less distance and consists of all other Zebda seedlings. This study additionally indicates that SSR markers are useful for distinguishing and characterizing mango genotypes. The genetic relatedness among these genotypes could provide useful information for conservation and selection of cross parents in breeding.
\end{abstract}

Keywords: Mango, Molecular characterization, Genetic diversity, SSR markers, Genetic relationships.

\section{INTRODUCTION}

Mango (Mangifera indica L.) is called 'king of fruits' due to its rich taste, flavor, color, production volume and long shelf life. It hails from Anacardiaceae family and it is a diploid plant with 20 pairs of chromosomes and a tiny genome size of $439 \mathrm{Mbp}$ (Viruel et al., 2005). Genetic enhancement of mango cultivars is complex by their reproductive system. Some intrinsic characteristics including high level of heterozygosity, long juvenile phase, only one seed per fruit, and heavy fruit drop leading to low maintenance of crossed fruits (Kepiro and Roose, 2010). The crosspollination nature and a wide range of common agroclimatic conditions have involved in a wide genetic diversity of mango (Abdalla et al., 2006). In polyembryonic cultivars, seedlings originate from somatic tissue and from a zygote, but differentiating between the two seedlings types can be confused (Rocha et al., 2014). Also, polyembryony makes breeding schemes complicated. Previously, the morphological traits were regarded the base of mango characterization (Farooq and Azam, 2002), but identification depending on morphological features is in competent and inaccurate. Furthermore, morphological characters are complicated due to the continual nature of the crop, vulnerably to environmental conditions and their restricted number (Kundan, 2013). Newly, molecular markers, based on polymorphisms at the DNA level, are increasingly used and proved effective to assess genetic diversity. Data based on molecular markers such as Amplified Fragment Length Polymorphism (AFLP), Restriction Fragment Length Polymorphism (RFLPs) and Random Amplified Polymorphic DNA (RAPD) has been utilized to identify variant genotypes. Microsatellites, also known as Simple-Sequence Repeats (SSRs), constitute an appropriate tool for genotyping because of their co-dominant manner and their high levels of allelic diversity at different loci. The utility of microsatellite markers for assessing the genetic variability in a wide range of plants has been recently reported (Fatimah et al., 2016). On account of their high mutation rates and the ease of analysis, microsatellite markers were useful and effective for phylogenetic studies, genetic fingerprinting, and cultivar identification among different mango genotypes (Adato et al., 1995). In recent years, genetic markers are increasingly used for the study of genetic diversity. Therefore, the polymorphism determined by these markers is one of the valuable parameters for studying cultivars and understanding their genetic difference. The high reproducibility of microsatellite markers may be due to their huge number, distribution throughout the genome, co-dominant inheritance, neutrality with respect to selection, and ease automation of analytical procedures. This study used SSR analysis of thirty two genotypes of mango to estimate the genetic relatedness between two mango cultivars and seedlings resulting from polyemberyonic seeds.

\section{MATERIALS AND METHODS}

\section{Plant material and sampling}

Two Egyptian polyembryonic mango cultivars (Zebda and Ewais) were used in this study growing at Canal University farm - Ismailia - Egypt in October 2018. 10 mature, healthy mango fruits of each cultivar have been collected and the seeds were implanted at $35^{\circ} \mathrm{C}$ in sand \& soil mixture (50:50) and appropriate wetness. The germination ratio was calculated by dividing the germinated seeds by the total number of seeds. The number of samples obtained from Zebda 
was 17 and from Ewais was (13) with overall 32 samples including every parental samples were labeled. From 32 fresh, young, tender leaves including the parental samples, $5 \mathrm{~g}$ of each sample were taken and enveloped in aluminum foil and immediately conserved in liquid nitrogen tank to prevent endoenzymes activation.

\section{DNA extraction}

Total DNA of 32 samples were extracted by the CTAB method according to (Keb-Llanes et al., 2002). Mango leaves were crushed to fine powder by small amount of liquid nitrogen, around (200 mg) of powder was transferred to $(1.5 \mathrm{ml})$ Eppendorf tube then $800 \mu \mathrm{l}$ of preheated extraction buffer ( 2 g Cetyl trimethyl ammonium bromide (CTAB) (w/v), $100 \mathrm{mM}$ Tris- $\mathrm{HCl}$ PH8), 20 mM EDTA pH 8.0 (w/v), 1.4 M NaCl, 4\% PVP, $10 \mathrm{mM} \quad \beta$-mercaptoethanol) was added immediately vortexed for 30 seconds and incubated at $65^{\circ} \mathrm{C}$ for $60 \mathrm{~min}$. After incubation, Eppendorf tubes were centrifuged at $(4,696.8 \mathrm{xg})$ for $10 \mathrm{~min}$, the pellets discarded and the aqueous phase transferred to a new Eppendorf tube. Approximately $(250 \mu 1)$ of chloroform/iso-amyl alcohol (24:1) was add to each tube and mixed by inversion several times. The tubes were centrifuged at 13,000 rpm for $1 \mathrm{~min}$. The upper clear layer was transferred to new tube then $50 \mu \mathrm{l}$ of $7.5 \mathrm{M}$ ammonium acetate followed by $500 \mu \mathrm{l}$ of ice cold absolute ethanol were added and mixed gently and the mixture was incubated overnight at $-20^{\circ} \mathrm{C}$. The tubes were centrifuged at $(4,696.8 \mathrm{x}$ g) for $1 \mathrm{~min}$ and the pellets were washed twice with $70 \%$ ethanol, and dried for $15 \mathrm{~min}$. After washing, the pellets were dissolved in $35 \mu \mathrm{L}$ TE $(10 \mathrm{mM}$ Tris- $\mathrm{HCl} \mathrm{pH} 8.0 ; 1 \mathrm{mM}$ EDTA pH 8.0). To remove RNA, $4 \mu 1$ RNase A (10 $\mathrm{mg} / \mathrm{ml}$ ) were added and incubated at $65^{\circ} \mathrm{C}$ for $20 \mathrm{~min}$. The resulting DNA was stored at $-20^{\circ} \mathrm{C}$. To quantify
DNA, the samples were electrophoresised onto $1 \%$ agarose (1 $\mathrm{g}$ of agarose in $100 \mathrm{ml}$ of $1 \mathrm{x}$ TAE buffer) containing $10 \mu \mathrm{l} / \mathrm{ml}$ ethidium bromide by electrophoresis at $100 \mathrm{~V}$ for $45 \mathrm{~min}$. The samples were measured at $260 \backslash 280 \mathrm{~nm}$ by Nano Drop ${ }^{\circledR}$ ND-1000 (Thermo Fisher Scientific ${ }^{\mathrm{TM}}$, USA).

\section{DNA amplification}

In the current study, five SSR primers pairs were employed for PCR amplification as reported by Viruel et al. (2005), and Honsho et al. (2005). Three ESTSSR primers reported by Kumar (2015). These SSRs markers were synthesized by Alpha DNA, (Canada) Table (1). These primers were used to analyze the profile band of SSR markers namely (LMMA1, LMMA2, LMMA8, LMMA15, ESTD1, ESTD2, ESTD10 and MIAC-3) Table (1). The amplification mixture contained $12.5 \mu \mathrm{l}$ of master mix ready to use (dNTPs + Taq DNA polymerase $\left.+\mathrm{MgCL}_{2}\right) .2 .0 \mu \mathrm{L}$ of DNA $(20 \mathrm{ng} / \mu \mathrm{l}$,) $2.0 \mu \mathrm{l}$ of each primers $(10 \mathrm{ng} / \mu \mathrm{l})$ and $10.5 \mu \mathrm{l}$ demonized water to a final volume $25 \mu \mathrm{l}$. PCR reaction was executed in (IBPR laboratory. Institute, PTC-100 thermocycler, Co) as follows: $4 \mathrm{~min}$ at $94^{\circ} \mathrm{C}$ (initial denaturation) followed by 35 cycles for $30 \mathrm{~s}$ at $94^{\circ} \mathrm{C}$ (denaturation); $1 \mathrm{~min}$ at $60^{\circ} \mathrm{C}$ (annealing) and 2 $\min$ at $72^{\circ} \mathrm{C}$ for extension and a final extension at $72^{\circ} \mathrm{C}$ for $5 \mathrm{~min}$. The amplification products were run on an agarose gel and stained with ethidium bromide $(10 \mu \mathrm{l} /$ $100 \mathrm{ml}$ ) and visualized under by ultraviolet light. Gels were done by use Gene Sys Gbox System.

\section{Data analysis}

The reproducible bands from selected primers were scored visually and were recognized as polymorphic based on the presence (1) or absence (0) in the different samples regardless the differences in band intensity.

Table (1): List of 8 SSR primers and their sequence

\begin{tabular}{|c|c|c|c|c|c|}
\hline No & $\begin{array}{l}\text { Locus } \\
\text { name }\end{array}$ & Sequence $\left(5^{\prime}-3^{\prime}\right)$ & $\operatorname{Ta}\left(C^{\circ}\right)$ & $\begin{array}{c}\text { Accession } \\
\text { No }\end{array}$ & Reference \\
\hline 1 & LMMA1 & $\begin{array}{c}\text { F:ATGGAGACTAGAATGTACAGAG } \\
\text { R:ATTAAATCTCGTCCACAAGT }\end{array}$ & 53 & AY628373 & \multirow{4}{*}{$\begin{array}{l}\text { Viruel et al. (2005) } \\
\text { Viruel et al. }(\mathbf{2 0 0 5 )} \\
\text { Viruel et al. }(\mathbf{2 0 0 5 )} \\
\text { Viruel et al. }(2005)\end{array}$} \\
\hline 2 & LMMA 2 & $\begin{array}{l}\text { F:AAATAAGATGAAGCAACTAAAG } \\
\text { R:TTAGTGATTTTGTATGTTCTTG }\end{array}$ & 47 & AY628374 & \\
\hline 3 & LMMA8 & $\begin{array}{c}\text { F:CATGGAGTTGTGATACCTAC } \\
\text { R:CAGAGTTAGCCATATAGAGTG }\end{array}$ & 53 & AY628380 & \\
\hline 4 & LMMA15 & $\begin{array}{c}\text { F:AACTACTGTGGCTGACATAT } \\
\text { R:CTGATTAACATAATGACCATCT }\end{array}$ & 62 & AY628387 & \\
\hline 5 & MIAC_3 & $\begin{array}{l}\text { F: TAAGCTAAAAAGGTTATAG } \\
\text { R: CCATAGGTGAATGTAGAGAG }\end{array}$ & 53 & AB190346 & Honsho et al. (2005) \\
\hline 6 & ESTD1 & $\begin{array}{l}\text { F:TGCTAATTTAGGCACTACCG } \\
\text { R:ATCATTATCCACCTCCTCCT }\end{array}$ & 53 & - & \multirow{3}{*}{$\begin{array}{l}\text { Kamlesh (2015). } \\
\text { Kamlesh (2015). } \\
\text { Kamlesh (2015). }\end{array}$} \\
\hline 7 & ESTD2 & $\begin{array}{l}\text { F:TACCACTCGTAGCCTCAACT } \\
\text { R:CCATTGTCGTTGTTGTTATG }\end{array}$ & 53 & - & \\
\hline 8 & ESTD10 & $\begin{array}{l}\text { F:GATCTGACCCAACAAAGAAC } \\
\text { R:ACGTAGATCTGCTTAACCCA }\end{array}$ & 53 & - & \\
\hline
\end{tabular}


The percentage of polymorphism, the number of specific alleles and the observed heterozygosity (Ho) were calculated. The effective number of alleles (NE) was calculated for each locus using the formula: $\mathrm{NE}=$ $1 / \sum$ (E/F) 2 according to Hart and Clark (1997). The polymorphic information content (PIC) or heterozygosity index was calculated from the formula: $\mathrm{PIC}=1-\sum$ pi2 where pi is the frequency of each allele the discriminating power per locus (PD) was scored as reviewed by Nei (1973) with replacing the allele frequency by the fragment frequency (kloosterman et al., 1993). The matching fingerprints were estimated according to Jones (1972). All previous calculations and genetic parameters were executed with the programs Microsoft Excel, Quantity one, and GENEPOP version 1.31 (Raymond and Rouset, 1995).
The similarity degree was calculated according to Dice coefficient (Sneath and Sokal, 1973), using the SPSS software ver. 16.0. The dendrogram were created depending on the average Linkage (Between Groups) using all recorded fragments over all the loci used to elucidate the genetic relationships and similarity between all genotypes.

\section{RESULTS AND DISCUSSION}

\section{Experimental field:}

In this study, the polyembryony percentage was $71 \%$ with average of 3.4 seedlings/seed in Zebda and $83 \%$ with average of 2.6 in Ewais the germination ratio was recorded as $70 \%, 60 \%$ in Zebda, and Ewais respectively, (Table 2).

Table (2): Germination and polyembryony percentage in both "Zebda" and "Ewais" CV

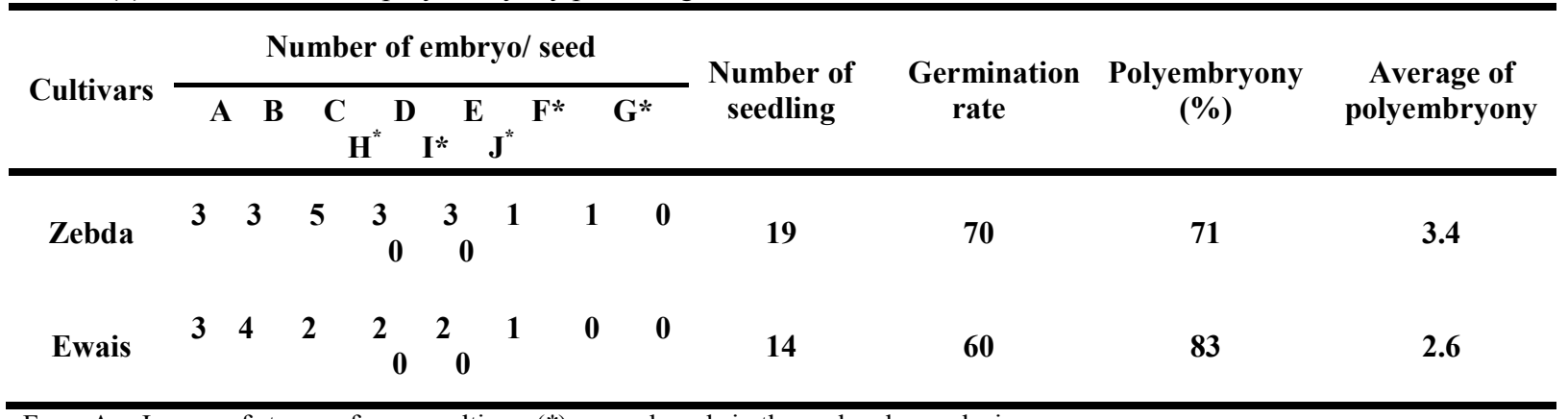

From A - J name of stones of every cultivar, $\left({ }^{*}\right)$ unused seeds in the molecular analysis

\section{Molecular characterization and the discrimination power}

The results of using SSR markers developed for mango cultivars (Viruel et al., 2005; Honsho et al., 2005; Kumar, 2015) gave successful amplifications across the 1SSR Markers Informative and Performance 32 samples. One marker (LMMA_15) did not show any polymorphism among the tested seedlings and gave only one monomorphic band at $220 \mathrm{bp}$. The LMMA_15 locus might be conserved or homozygous in the samples or homozygosity in the genome.

For the thirty two samples, other seven SSR markers produced total of 22 alleles with a high level of Polymorphism ( 100 percent). The high ratio of polymorphism might be a consequence of replication slippage (Powell et al., 1996) or it might be due to low genetic stability and high variability of the DNA sequences in the amplified non-coding regions of the mango genome (Fatima et al., 2018).

The overall size of amplified PCR products ranged from $60 \mathrm{bp}$ in LMMA_8 to $578 \mathrm{bp}$ in ESTD_2. This difference in size might correlate with the number of repeats within each particular locus (Cole, 2005). In view of such widely divergent sizes, the actual number of nucleotides in these alleles would need to be established by sequencing. This suggests a wide genetic diversity in the tested seedlings that may be used in mango breeding programs. The identification by SSR markers of allele size can be subjected to pair- wise comparison to detect genotypic differences (Galbacs et al., 2009).

The number of alleles per locus varied from 2 to 5 alleles with average number of 3 alleles per locus. ESTD_1marker has the largest number of alleles (5) Table (3). Whereas, the low number of alleles (2) in each of LMMA_2 marker and MIAC_3 marker might due to the quality of agarose used to resolve the amplified products or the exclusion of the monomorphic and spurious bands from analysis, reducing the number of alleles (Shah et al., 2013). Other explanations might be due to the 'short allele dominance', where, in heterozygote's including a short and a long allele, only the short allele is sufficiently amplified in the PCR reaction (Wattier et al., 1998). The variability in the number of alleles per locus could results from diverse locus-specific mutation rates and reproduces strong variations in allelic diversity between SSRs loci (Piyusha and Singh, 2018). Higher allelic numbers were detected in six cultivated mangoes and two wild species by Chunwongse et al. (2015). The comparisons with the allelic diversities reported by other studies should be regarded with caution, taking into consideration the different sample sizes used. Moreover, the same mean number of alleles may not indicate the same amount of variability (Paiva et al., 2014). Two markers, ESTD_2 and ESTD_10 did not produce any alleles that distinguish Ewais seedlings in this study. 


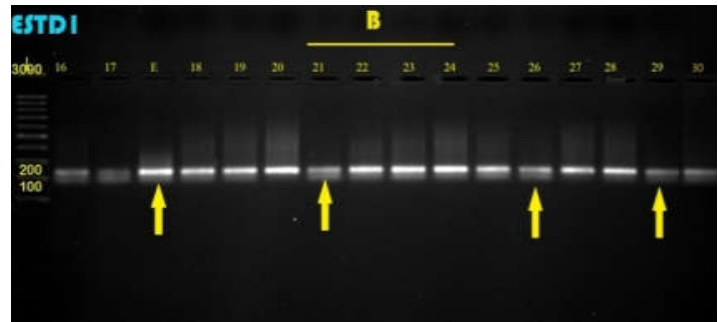

Fig. (1): Profile band of ESTD 1 primer of Zebda . $L=100$ bp ladder, $\mathrm{Z}=$ mother sample, $1-15=$ seedlings samples, $\mathrm{C}=$ stone code that contain $[7,8,9,10,11]$, The left arrow $=$ mother sample bands, the middle arrow $=$ different band (tri band), the last arrow $=$ different band (single band)

However, from the 7 SSR markers analyses of 32 mango seedlings, either one or two PCR products were observed for each sample, representing homogeneity and heterogeneity, respectively. One or more of the SSR loci detected multiple bands, which can be attributed to the allopolyploid nature of mango as described by Mukherjee (1972).

Meanwhile two loci (ESTD_1 and ESTD_2) produced more bands than expected based on the diploid construction of this species, this may be due to the duplication of these loci or the genomic rearrangements accumulated and thus it is enable to describe as multiple loci (Callen et al., 1993; Viruel et al., 2005).

Effective number of alleles $(\mathrm{Ne})$ is the measure of allelic evenness. In this study, the results showed that the effective number of alleles $(\mathrm{Ne})$ for the polymorphic markers ranged from 1.7, for LMMA _2 and MIAC_3 to 3.4 for ESTD_1 with average value of 1.47. The total number of effective alleles produced by the 7 SSR loci was 10.3. Table (3) showed that the average of effective number of alleles was lower (1.47) than observed number of alleles (3). Because of low frequencies alleles had little contribution to the effective number of alleles. According to the selective standard of the microsatellite loci, it ought to have at least four alleles to be considered supportive for the evaluation of genetic diversity. Bases on this criterion, the 7 SSR loci used in this study were useful for the evaluation of genetic diversity in 32 Mango genotypes. These results imply that abundant genetic polymorphism exist in mango cultivars.

Heterozygosity $(\mathrm{He})$ refers to the presence of different alleles at one or more loci on homologous chromosomes. Heterozygosity per locus varied from 0.00 (MIAC-3 and ESTD_10) to 0.75 ((LMMA1)) with an average of 0.36 (Täble 3 ). The heterozygosity observed at some of the loci could also be due to high mutational rate and mutational bias at SSR loci. The loci with a large number of repeat units (SSR units) tend to show a high mutational rate. As a result, any mutations in any one of the alleles may create a heterozygous condition (Bharathi, 2011). The measure of the level of heterozygosity across loci can be used as an indicator of the amount of genetic variability (Zulkifli et al., 2012). However, Allelic diversity and

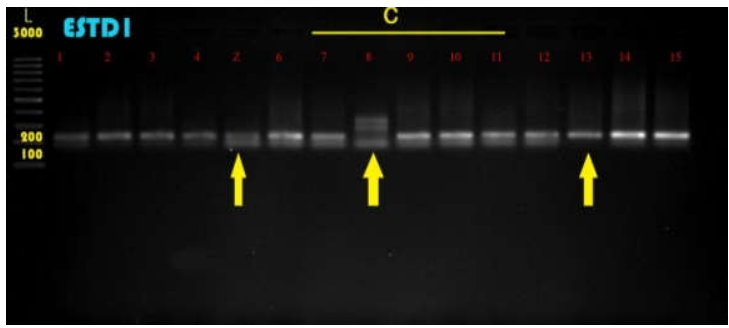

Fig. (2): Profile band of ESTD_1 primer of Ewais. L = 100 bp ladder, $\mathrm{E}=$ mother sample, $18-30=$ seedlings samples, $\mathrm{B}$ $=$ stone code that contain $[21,22,23,24]$, The left yellow arrow $=$ mother sample bands, the other yellow arrows $=$ clear different bands

heterozygosity are important features for the establishment of microsatellite markers for linkage studies (Chiaramonte et al., 2002).

Polymorphic Information content (PIC) value varied from 0.41 (LMMA 2) to 0.70 (ESTD 1) with average of 0.57 . The broad range of PIC values in present study was indicative of the presence of unique alleles in some seedlings which facilitates their differentiation from another. According to Botstein et al. (1980), the mean value of PIC recodes more than 0.5 that is considered informative markers and reflected the high level of polymorphisms of the used set of microsatellites and heterogeneity in 32 mango seedlings. This is higher than that reported by Schnell et al. (2005) in their work with 15 microsatellite loci ranging from 0.21 to 0.63 for the polymorphic among59 Florida cultivars and four related species from the USDA germplasm collection for mango. This may probably be due to the different diverse genotypes analyzed and to the different number of analyzed samples. Nevertheless, the PIC depended on the number of alleles detected and on their distribution frequency. Also, PIC was influenced by location of primers in the genome used for study and genotype sensitivity to the method used (Pachauri et al., 2013). Hence, PIC values increased proportionally in ESTD 1, ESTD 2 and LMMA 1 with increasing heterozygosity at each locus. Whereas, the lower PIC value (0.41) for LMMA_2 might be attributed to the concentration of gene frequencies, which leads to deviation from the condition of maximum information content of a locus. This occurs when all alleles have similar frequencies (Paiva, et al., 2014). The discrimination power (Dp) was found to be high in the majority of the 7 SSR markers (Table3), ranged between 0.11 and 0.72 with an average of 0.50 per locus. However, the discrimination power is an extension of the polymorphism information content (PIC), which actually describes the efficiency of a given marker to discriminate between genotypes, i.e., the probability that two randomly selected individuals have different arrays (Anderson et al., 1993). Thus, high PIC parallel with Dp values exhibited that these markers have the potential to disclose allelic variation and each of these markers had a greater affinity towards discriminating between two genotypes (Ashraf et al., 2016). 
Table (3): Various parameters related to7markers for SSR analysis in 32 Mango seedlings

\begin{tabular}{lccccccc}
\hline $\begin{array}{c}\text { SSR loci } \\
\text { code }\end{array}$ & Size & $\begin{array}{c}\text { Total } \\
\text { alleles (na) }\end{array}$ & NE $^{\text {a }}$ & $\begin{array}{c}\text { Polymorphic } \\
\text { band }\end{array}$ & HO $^{\mathbf{b}}$ & PIC $^{\mathbf{c}}$ & DP $^{\mathbf{d}}$ \\
\hline LMMA_1 & $150-322$ & 3 & 2.7 & 3 & 0.75 & 0.63 & 0.60 \\
LMMA_2 & $95-200$ & 2 & 1.7 & 3 & 0.47 & 0.41 & 0.44 \\
LMMA_8 & $60-378$ & 3 & 2.3 & 3 & 0.06 & 0.56 & 0.57 \\
MIAC_3 & $186-205$ & 2 & 1.7 & 2 & 0.00 & 0.49 & 0.50 \\
ESTD_1 & $188-330$ & 5 & 3.4 & 5 & 0.66 & 0.70 & 0.72 \\
ESTD_2 & $188-578$ & 4 & 3.1 & 4 & 0.56 & 0.68 & 0.55 \\
ESTD_10 & $80-214$ & 3 & 2.1 & 3 & 0.00 & 0.53 & 0.11 \\
Total & & 22 & 10.3 & & 2.5 & 4 & 3.49 \\
Average & & 3 & 1.47 & & 0.36 & 0.57 & 0.50 \\
\hline
\end{tabular}

\section{Genetic similarity and cluster analysis}

Genetic Similarity (GS) matrices constructed on shared allele bases over 32 tested seedlings varied from 0.12 to 1.00 Table (4). The highest percentage of genetic similarity $(100 \%)$ was in each cultivar and its seedlings. This indicates that the seedlings of both cultivars are highly similar with their mothers. In general, the lowest percentage (12\%) was recorded between seedling (Z_B_S1) and each one of 4 seedlings of Ewais, namely (E_E_S1, E_E_S2, E_B_S1 and E_C_S2). The huge variation between the two mango cultivars might be due to a long period of cultivation, polyembryonic nature and germplasm exchange followed by much possibility of hybridization and high clonal heterozygosity. However, Ewais cultivar and its seedlings showed a great similarity among them. This deserves further exploration (Table 4 and Figure 3 ). Regarding to Zebda cultivar and their seedlings, some distinctions in genetic similarity were noticed and ranged from $52 \%$ to $100 \%$. The lowest percentage of genetic similarity (52\%) was between Z_B_Sland Z_D_S2. This result might be due to mango pollinators (mango is anallogamus, cross pollinated species) and, especially, human intervention by transferring specimens fromone population to another (Kiambi et al., 2005). Up to this point, it is needed to expand the scope of gene flow detection in further studies. The dendrogram can be grouped into two major clusters (I and II). Cluster I consists of Ewais s seedlings exhibiting 94-100\% genetic similarity among them (Figure 3). Cluster II consists of all seedlings of Zebda cultivar exhibiting $52-100 \%$ genetic similarity and divided to two sub-clusters. Seedling (Z_C_S2) was the most divergent in first sub cluster and second sub cluster exhibited less distance and consists of all other Zebda seedlings.

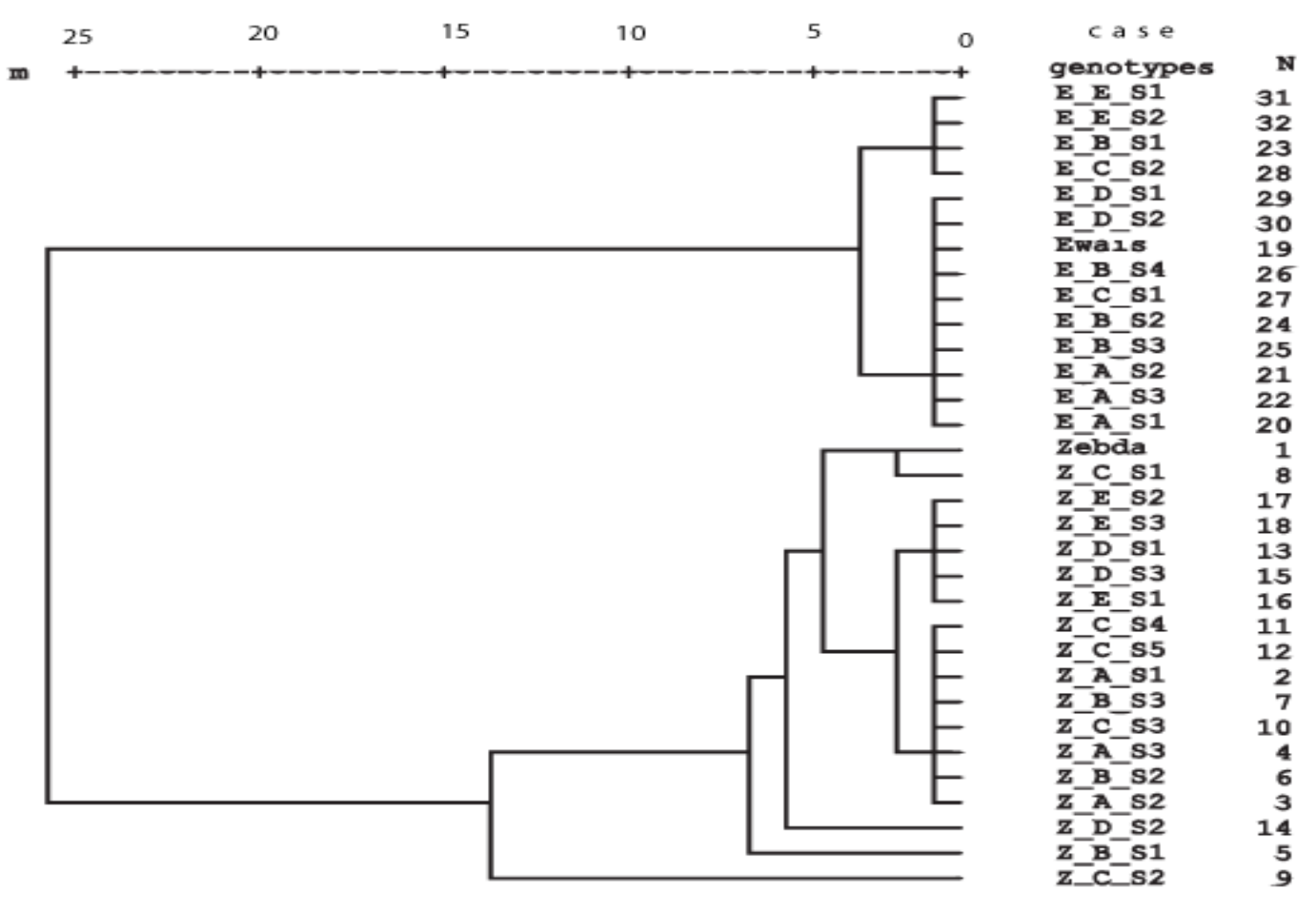

Fig. (4): Dendrogram using Average Linkage (Between Groups) Rescaled Distance Cluster Combine 
Table (4): Pair-wise similarities matrix of 32 mango accessions according to the index of (Sneath and Sokal, 1973) based on SSRs data analysis using SPSS program

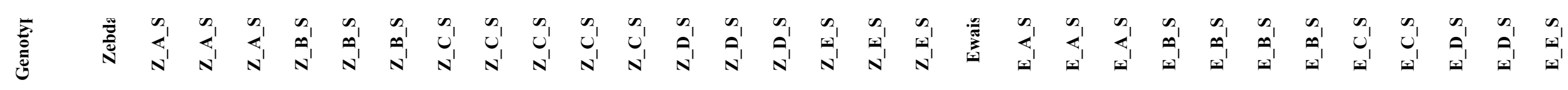

Zebd:
Z_A_s
Z_A_s
Z_A_s
Z_B_s
Z_B_s
Z_B_s
Z_C_s
Z_C_s
Z_C_c
Z_C_s
Z_C_s
Z_D_s
Z_D_s
Z_D_s
Z_E_s
Z_E_s
Z_E_s
Ewai
E_A_s
E_A_s
E_A_s
E_B_s
E_B_s
E_B_s
E_B_s
E_C_s
E_C_s
E_D_s
E_D_s
E_E_s
E_E_s

$$
\begin{array}{ll}
1.0 & \\
0.9 & 1.0
\end{array}
$$$$
\begin{array}{lll}
0.9 & 1.0 & 1.0
\end{array}
$$$$
\begin{array}{llll}
0.9 & 1.0 & 1.0 & 1.0
\end{array}
$$$$
\begin{array}{lllll}
0.7 & 0.8 & 0.8 & 0.8 & 1.0
\end{array}
$$$$
\begin{array}{llllll}
0.9 & 1.0 & 1.0 & 1.0 & 0.8 & 1.0
\end{array}
$$$$
\begin{array}{llllllll}
0.9 & 1.0 & 1.0 & 1.0 & 0.8 & 1.0 & 1.0
\end{array}
$$$$
\begin{array}{llllllll}
0.9 & 0.9 & 0.9 & 0.9 & 0.8 & 0.9 & 0.9 & 1.0
\end{array}
$$$$
\begin{array}{lllllllll}
0.6 & 0.6 & 0.6 & 0.6 & 0.5 & 0.6 & 0.6 & 0.7 & 1.0
\end{array}
$$$$
\begin{array}{llllllllll}
0.9 & 1.0 & 1.0 & 1.0 & 0.8 & 1.0 & 1.0 & 0.9 & 0.6 & 1.0
\end{array}
$$$$
\begin{array}{lllllllllll}
0.9 & 1.0 & 1.0 & 1.0 & 0.8 & 1.0 & 1.0 & 0.9 & 0.6 & 1.0 & 1.0
\end{array}
$$$$
\begin{array}{llllllllllll}
0.9 & 1.0 & 1.0 & 1.0 & 0.8 & 1.0 & 1.0 & 0.9 & 0.6 & 1.0 & 1.0 & 1.0
\end{array}
$$$$
\begin{array}{lllllllllllll}
0.8 & 0.9 & 0.9 & 0.9 & 0.8 & 0.9 & 0.9 & 0.9 & 0.6 & 0.9 & 0.9 & 0.9 & 1.0
\end{array}
$$$$
\begin{array}{llllllllllllll}
0.7 & 0.8 & 0.8 & 0.8 & 0.7 & 0.8 & 0.8 & 0.8 & 0.5 & 0.8 & 0.8 & 0.8 & 0.9 & 1.0
\end{array}
$$$$
\begin{array}{lllllllllllllll}
0.8 & 0.9 & 0.9 & 0.9 & 0.8 & 0.9 & 0.9 & 0.9 & 0.6 & 0.9 & 0.9 & 0.9 & 1.0 & 0.9 & 1.0
\end{array}
$$$$
\begin{array}{llllllllllllllll}
0.8 & 0.9 & 0.9 & 0.9 & 0.8 & 0.9 & 0.9 & 0.9 & 0.6 & 0.9 & 0.9 & 0.9 & 1.0 & 0.9 & 1.0 & 1.0
\end{array}
$$$$
\begin{array}{lllllllllllllllll}
0.8 & 0.9 & 0.9 & 0.9 & 0.8 & 0.9 & 0.9 & 0.9 & 0.6 & 0.9 & 0.9 & 0.9 & 1.0 & 0.9 & 1.0 & 1.0 & 1.0
\end{array}
$$

Whereas $\mathrm{Z}$ and $\mathrm{E}$ refers to Zebda and Ewais mothers, (A-E) refers to stone key and (S) refers to seedling key 


\section{CONCLUSION}

The use of SSR analysis in the present study revealed an extensive amount of divergence leading to cultivar identification in mango. The level of polymorphism observed was high (100\%), indicating a wide and diverse genetic based for 32 samples used. According to PIC, Ho and DP values, SSR markers seem to be the suitable technique for characterization mango genotypes. The genetic similarity values varied between 0.12 and 1.00 over 32 samples. This might shed more light on the genetic relatedness of mango cultivar sand assist breeders to set up the appropriate guidelines for successful breeding of mango cultivars based on the established relationships. Finally, this study could provide useful information to address breeding programs and germplasm resource management.

\section{REFERENCES}

Abdalla, A. E. M., S. M. Darwish, Eman H. E. Ayad and Reham M. El-Hamahmy (2007). Egyptian mango by-product 1 . Compositional quality of mango seed kernel. Food Chemistry, 103: 1134-1140. 10.1016/j.foodchem.2006.10.017.

Adato, A., D. Sharon, U. Lavi, J. Hillel and S. Gazit (1995). Application of DNA fingerprints for identification and genetic analyses of mango (Mangifera indica) genotypes. Journal of the American Society for Horticultur, 120(2): 259-264.

Anderson, J. A., G. A. Churchill, J. E. Autrique, S. D. Tanksley and M. E. Sorrells (1993). Optimizing parental selection for genetic linkage maps. Genome, 36: 181-186.

Ashraf, J., W. Malik, M. Iqbal, A. Khan, A. Qayyum, E. Noor, M. Abid, H. M. Cheema and M. Q. Ahmad (2016). Comparative Analysis of Genetic Diversity among Bt Cotton Genotypes Using EST-SSR, ISSR and Morphological Markers. Journal of Agricultural Science and Technology, 18: 517-531.

Bharathi, S. C. Immanuel, N. Pothiraj, K. M. Thiyagarajan and R. Rabindran (2011). Genetic parameters of variability, correlation and path coefficient studies for grain yield and other yield attributes among rice blast disease resistant genotypes of rice (Oryza sativa L.). African Journal of Biotechnology, 10(17): 3322-3334.

Botstein, D., R. L. White, M. Skolnick and R. W. Davis (1980). Construction of a genetic linkage map in man using restriction fragment length polymorphisms. The American Journal of Human Genetics. 32: 314-31.

Callen, D. F., A. D. Thompson, Y. Shen, H. A. Phillips and R. I. Richards, J. C. Mulley and G. R. Sutherland (1993). Incidence and origin of null alleles in the (AC)n microsatellite markers. Am. J. Human. Genet, 52: 922-927.
Chiaramonte, R., M. Sabbadini, F. Balordi, P. Comi and G. V. Sherbet (2002). Allele frequency of two intragenic microsatellite loci of SEL1L gene in Northern Italian population. Molecular and cellular biochemistry, 232: 159-161.

Chunwongse, C., C. Phumichai, P. Tongyoo, N. Juejun and J. Chunwongse (2015). Development of di-nucleotide microsatellite markers and construction of genetic linkage map in mango (Mangifera indica L.). Songklanakarin Journal of Science \& Technology, 37(2).

Cole, T. (2005). Allelic and population variation of microsatellite loci in aspen (Populus tremuloides). New Phycologist, 167: 155-164.

Farooq, S., and F. Azam (2002). Molecular markers in plant breeding-II. Some pre-requisites for use. Pakistan journal of biological Sciences, 5(10): 1141-1147.

Fatima, S., K. Chaudhari, S. Akhtar and M. Amjad (2018). Mapping QTLs for yield and yield components under drought stress in bread wheat (Triticum aestivum L.). Applied Ecology and Environmental Research, 16(4): 4431-4453.

Fatimah, F., A. Husni, M. Kosmiatin, K. Karsinah and M. Baroya (2016). Characterization of Zygotic and Nucellar Embryo of Six Indonesian Mango Cultivars Using Molecular Markers. In Annales Bogorienses (Vol. 20, No. 2, pp. 69-75).

Hart, L. and A. G. Clark (1997). Principles of population Genetics. $3^{\text {rd }}$ edition. Sinauer Associates, Inc, Sunderland, U.S.A.

Honsho, C., K. Nishiyama, Eiadthong Wand Yonemori K. (2005). Isolation and characterization of new Microsatellite markers in mango (Mangifera indica). Molecular Ecology Notes, 5: $152-154$

Jones, D. A. (1972). Blood Samples: probability of discrimination. Journal of the Forensic science Society, 12: 355-359.

Keb-Llanes, M., G. González, B. Chi-Manzanero and D. Infante (2002). A rapid and simple method for small-scale DNA extraction in Agavaceae and other tropical plants. Plant Molecular Biology Reporter, 20(3): 299-300.

Kepiro, J. L. and M. L. Roose (2010). AFLP markers closely linked to a major gene essential for nucellar embryony (apomixis) in Citrus maxima $\times$ Poncirus trifoliata. Tree genetics $\&$ genomes, 6(1): 1-11.

Kiambi, D. K., H. J. Newbury, B. V. Ford-Lloyd and I. Dawson (2005). Contrasting genetic diversity among Oryza longistaminata (A. Chev et Roehr) populations from different geographic origins using AFLP. African Journal of Biotechnology, 4(4): 308-317.

Kloosterman, A. D., B. Budowlw and P. Daselaar (1993). PCR-amplification and detection of human DIS80 VNTR locus-Amplification condition, population genetics and application 
in forensic analysis. International Journal of legal Medicine, 105: 257-264.

Kumar, K. (2015). DNA marker-based differentiation of zygotic and nucellar seedlings and identification of polymorphic microsatellite markers among parental mango genotypes (Doctoral dissertation, Division of Fruits and Horticultural Technology Icar-Indian Agricultural Research Institute New Delhi110

012).

http://krishikosh.egranth.ac.in/handle/1/58100 33532.

Kundan Kishore (2013). Polyembryony. ResearchGate, chapter (15), pp. 355-372.

Mukherjee, S. K. (1972). Origin of mango Economic Botany, 26: 260-264

Nei, M. (1973). Analysis of gene diversity in subdivided populations. Proc. Natl. Acad. Sci. USA, 70: 3321-3323.

Pachauri, V., N. Taneja, P. Vikram, N. K. Singh and S. Singh (2013). Molecular and morphological characterization of Indian farmers' rice varieties (Oryza sativa L.). Australian Journal of Crop Science, 7(7): 923.

Piyusha, S. and N. K. Singh (2018). SSR Molecular Markers are efficient tools for finding Genetic Diversity in Bread Wheat. International Journal of Current Microbiology and Applied Sciences, 12: 1098-1105.

Powell, W., M. Morgante, C. Andre and A. Rafalski (1996). The comparison of RFLP, RAPD, AFLP and SSR (Microsatellite) markers for germplasm analysis. Mol. Breed. 2: 225-238.

Paiva, C. L., A. P. Viana, E. A. Santos, J. C. D. O. Freitas, R. N. O. Silva and E. J. D. Oliveira (2014). Genetic variability assessment in the genus Passiflora by SSR markers. Chilean journal of agricultural research, 74(3): 355 360.
Raymond, M. and F. Rouset (1995). GENEPOP (version 1.31): population genetics software for exact test and ecumenicism. J. Hered 86:248-249.

http://whbiomed.curtin.edu.au/gene-pop/

Rocha, A., T. M. F. Salomão, D. L. de Siqueira, C. D. Cruz and L. C. C. Salomão (2014). Identification of 'Ubá' mango tree zygotic and nucellar seedlings using ISSR markers. Revista Ceres, 61(5): 597-604.

Schnell, R. J., C. T. Olano, W. E. Quintanilla and A. W. Meerow (2005). Isolation and characterization of 15 microsatellite loci from mango (Mangifera indica L.) and crossspecies amplification in closely related taxa Molecular Ecology Notes, 5: 625-627.

Shah, S. M., S. A. Naveed and M. Arif (2013). Genetic diversity in Basmati and non- Basmati rice varieties based on microsatellite markers. Pak J. Bot., 45: 423-431.

Sneath, P. H. and R. R. Sokal (1973). Numerical taxonomy. Freeman. San Francisco, 573 pp.

Viruel, M. A., P. Escribano, M. Barbieri, M. Ferri and J. I. Hormaza (2005). Fingerprinting, embryo type and geographic differentiation in mango (Mangifera indica L., Anacardiaceae) with microsatellites. Molecular Breeding, 15(4): 383-393.

Wattier, R., C. Engel, P. Saumitou-Laprade and M. Valero (1998). Short allele dominance as a source of heterozygote deficiency at microsatellite loci: Experimental evidence at the dinucleotide locus Gv1CT in Gracilaria gracilis (Rhodophyta). Molecular Ecology, 7: 1569-1573.

Zulkifli, Y., L. Maizura and S. Rajinder (2012). Evaluation of MPOB oil palm germplasm (Elaeis guineensis) populations using ESTSSR. J Oil Palm Res, 24: 1368-1377. 


\section{تقلير الخصائص الجزيئية لبادرات ناثئة من صنفين من الماتجو المصرية عديدة الأجنة باستخدام

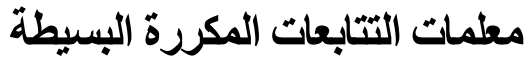

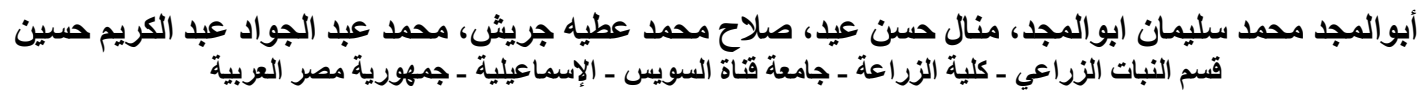

في هذه الدراسة نم تقدير الخصائص الجزيئية والتنوع الوراثي بين صنفين من أصناف المانجو المصرية التجارية عديدة الأجنة وهما

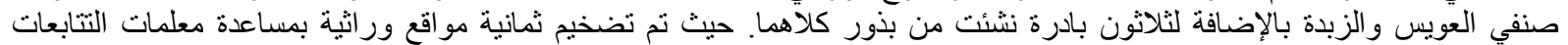

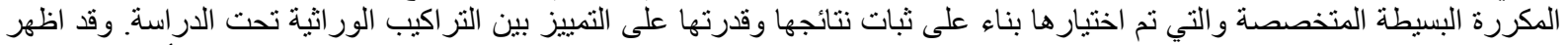

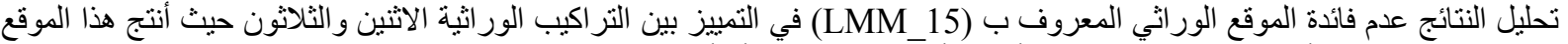

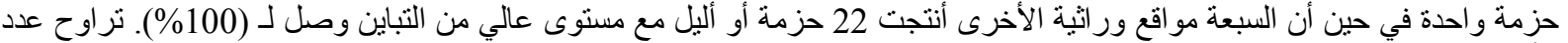

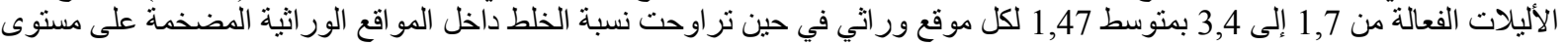

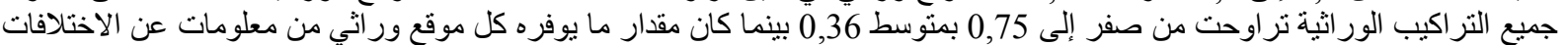

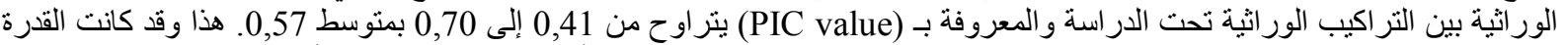

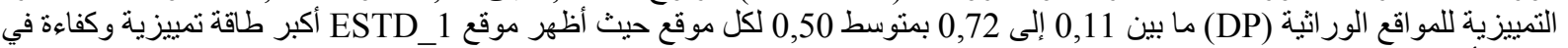

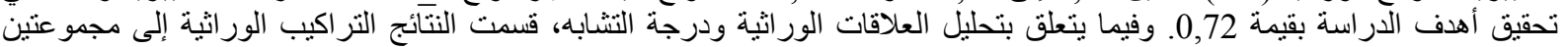
رئيستين وفقا لدرجة التشابه والتي ظهرت ما بين المنئ النخفضة بنسبة 0,12 إلى المرتفعة جدا بنسبة 100\% بمتوسط

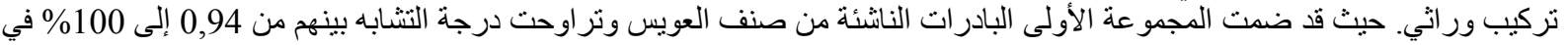

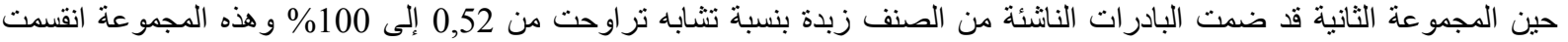

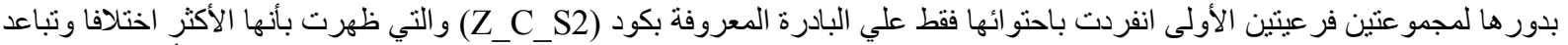

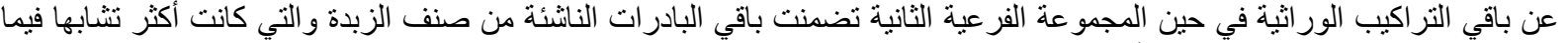

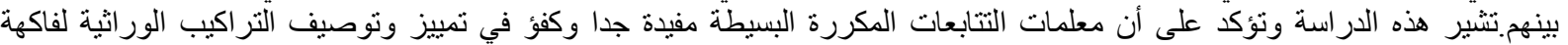

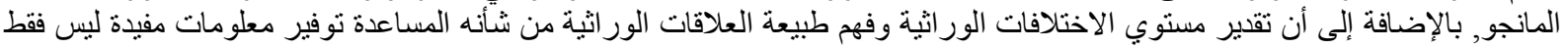

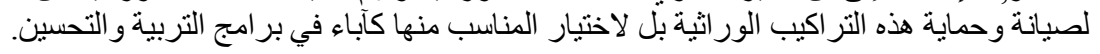
الكلمات الدالة: المانجو، الخصائص الجزيئة، الاختلافات الوراثية، العلاقات الوراثية، معلمات التتابعات المكررة البسبطة. 